Article

\title{
Investigation of Separated Two-Phase Thermosiphon Loop for Relieving the Air-Conditioning Loading in Datacenter
}

\author{
Hafiz M. Daraghmeh ${ }^{1}{ }^{\mathbb{D}}$, Mohammed W. Sulaiman ${ }^{1}{ }^{\mathbb{D}}$, Kai-Shing Yang ${ }^{2}$ and \\ Chi-Chuan Wang $1, *$ (D) \\ 1 Department of Mechanical Engineering, National Chiao Tung University, Hsinchu 300, Taiwan; \\ hafizmech.me02g@nctu.edu.tw (H.M.D.); eng.sulaiman86@yahoo.com (M.W.S.) \\ 2 Green Energy \& Environment Research Laboratories, Industrial Technology Research Institute, \\ Hsinchu 300, Taiwan; ksyang@itri.org.tw \\ * Correspondence: ccwang@mail.nctu.edu.tw; Tel.: +886-3-5712121
}

Received: 28 November 2018; Accepted: 24 December 2018; Published: 29 December 2018

\begin{abstract}
This study investigates the feasibility of using R-134a filled separated two-phase thermosiphon loop (STPTL) as a free cooling technique in datacenters. Two data center racks one of them is attached with fin and tube thermosiphon were cooled by CRAC unit (computer room air conditioning unit) individually. Thermosiphon can help to partially eliminate the compressor loading of the CRAC; thus, energy saving potential of thermosiphon loop was investigated. The condenser is a water-cooled design and perfluoroalkoxy pipes were used as adiabatic riser/downcomer for easier installation and mobile capability. Tests were conducted with filling ratio ranging from 0 to $90 \%$. The test results indicate that the energy saving increases with the rise of filling ratio and an optimum energy savings of $38.7 \%$ can be achieved at filling ratios of $70 \%$, a further increase of filling ratio leads to a reduction in energy saving. At a low filling ratio like $10 \%$, the evaporator starves for refrigerant and a very uneven air temperature distribution occurring at the exit of data rack. The uneven temperature distribution is relieved considerably when the evaporator is fully flooded. It is also found that the energy saving is in line with the rise of system pressure. Overfilling of the evaporator may lead to a decline of system pressure. A lower thermal resistance occurs at high filling ratios and higher ambient temperature.
\end{abstract}

Keywords: datacenter; free cooling; two-phase flow; thermosiphon; separated loop; PFA pipe

\section{Introduction}

Effective thermal management in datacenter has become more and more important. This is because nowadays the electrical energy consumption of datacenters represents $1.1 \sim 1.5 \%$ of the world's total electricity consumption. Besides, traditional cooling systems of datacenter consume nearly $50 \%$ of the total energy. Moreover, according to industry predictions, data centers' annual power demand can reach up to $20 \%$ [1]. In this regard, recent researches had focused on implementing new efficient cooling techniques that might help to minimize the electrical power usage and then minimize the costs spent on thermal energy management. Thus, many recent studies had employed free cooling techniques such as direct/indirect airside and waterside free cooling [2]. By introducing these techniques to datacenter, the compressor load can be partially or completely relieved. However, mechanical piping system of such techniques requires long distance transportation of air or water. In other words, they consume a lot of electrical energy through fans or pumps. One alternative for energy-saving technique is based on heat pipe for its passive feature. Using heat pipe for data center cooling such as thermosiphon is being 
considered as a promising technology for effective heat removal with short distance transportation. Moreover, thermosiphon features unique characteristics such as the simple structure, low-cost and high effective thermal conductivity. For the best energy savings, integrated system of mechanical refrigeration and thermosiphon (ISMT) has been considered as an ideal economization system; that is because it is a gravity driven device which does not require pumping power and auxiliary refrigeration system, thereby reducing considerable greenhouse gas emissions. Furthermore, thermosiphon can work even when the temperature difference between indoor and outdoor is small. ISMT has been used widely for energy saving purposes. Han et al. [3] developed a new ISMT in high heat density mobile phone stations. The integrated system which combines the traditional vapor compression cycle and thermosiphon cycle, consumed about 34.3-36.9\% less energy than traditional cooling systems. Zhang et al. [4] proposed an ISMT consists of two circulation loops: a mechanical refrigeration loop and a thermosiphon loop. The experimental investigation results of the performance of the ISMT showed an annual energy-saving up to $47.3 \%$. Zhang et al. [5] studied the effect of air flow rate and geometric parameters on the performance of the ISMT. The results showed that cooling capacity and circulation flow rate increased with the riser diameter of thermosiphon and air flow rate but decreased with the tube length.

Generally, thermosiphon can be classified into two main categories. The first one is similar to a single heat pipe with close ends and it comprises of three sections; evaporator, adiabatic section and condenser. The other kind of thermosiphon is the separated two-phase thermosiphon loop (STPTL), sometimes called loop thermosiphon. It is called separated because the evaporator and the condenser are separated and located in different levels, and they are connected to each other by two adiabatic pipes; vapor line (riser), and liquid line (downcomer). Amongst these two kinds of thermosiphon systems, the loop thermosiphon is more reliable in datacenter environment because of its higher capability to transfer heat, the ability to transfer heat at small temperature difference, and since evaporator and condenser are separated, they can be located comparatively far away from each other, which enables them to transfer heat to a longer distance [6]. Many researchers had adopted the STPTL for thermal energy management of datacenters [7-10]. They studied the heat transfer performance of the STPTL and the factors that influence the heat transfer capacity of the loop, such as the thermosiphon structure, working fluid, operating conditions and the like. Among these factors, selecting the working fluid is the most crucial factor. For example, some of the aforementioned studies had investigated the usage of carbon dioxide (R-744) as a working fluid for free cooling in datacenters. R-744 was selected because of its excellent thermodynamic properties (high heat transfer rate and low pressure drop). However, R-744 is not workable in some conditions since it has low critical temperature and comparatively high pressure. Therefore, it can only be used for two-phase thermosiphon systems when the working temperature of thermosiphon is less than $31.1^{\circ} \mathrm{C}$ [11], which makes it infeasible for high density datacenter racks. Recently, electrical power density of datacenter racks is dramatically increasing. Hence, testing thermosiphon heat exchangers that uses refrigerants with higher critical temperature is more beneficial. Generally, two kinds of experimental researches had been conducted; the first kind of experiment examined different kind of refrigerants in order to decide which among them gives the best heat transfer capability for specific operating conditions. The other focused on finding the optimal filling ratio for specific kind of refrigerant that gives the best heat transfer capability. In this paper, an experimental study has been conducted to compare the power consumption of two identical datacenter racks; one of them is combined with thermosiphon (evaporator) as a part of the STPTL. Also, each rack's cooling system was tested separately under the same operating and environmental conditions. The average airside outlet temperature of the traditional rack was measured at constant heating load in the range of $28.7 \sim 38.9^{\circ} \mathrm{C}$. Thus, $\mathrm{R}-134 \mathrm{a}$ has been selected as a working fluid, since its critical temperature is $101.06^{\circ} \mathrm{C}$ [12]. It is worth mentioning that the STPTL's adiabatic section that connects the evaporator (thermosiphon) and the condenser is a Teflon pipe made from fluoropolymers called perfluoroalkoxy (PFA). The soft pipe design offers a 
flexible and mobile arrangement of condenser. A summary of literatures related to STPTL is shown in Table 1.

Table 1. Related literature in association with STPTL.

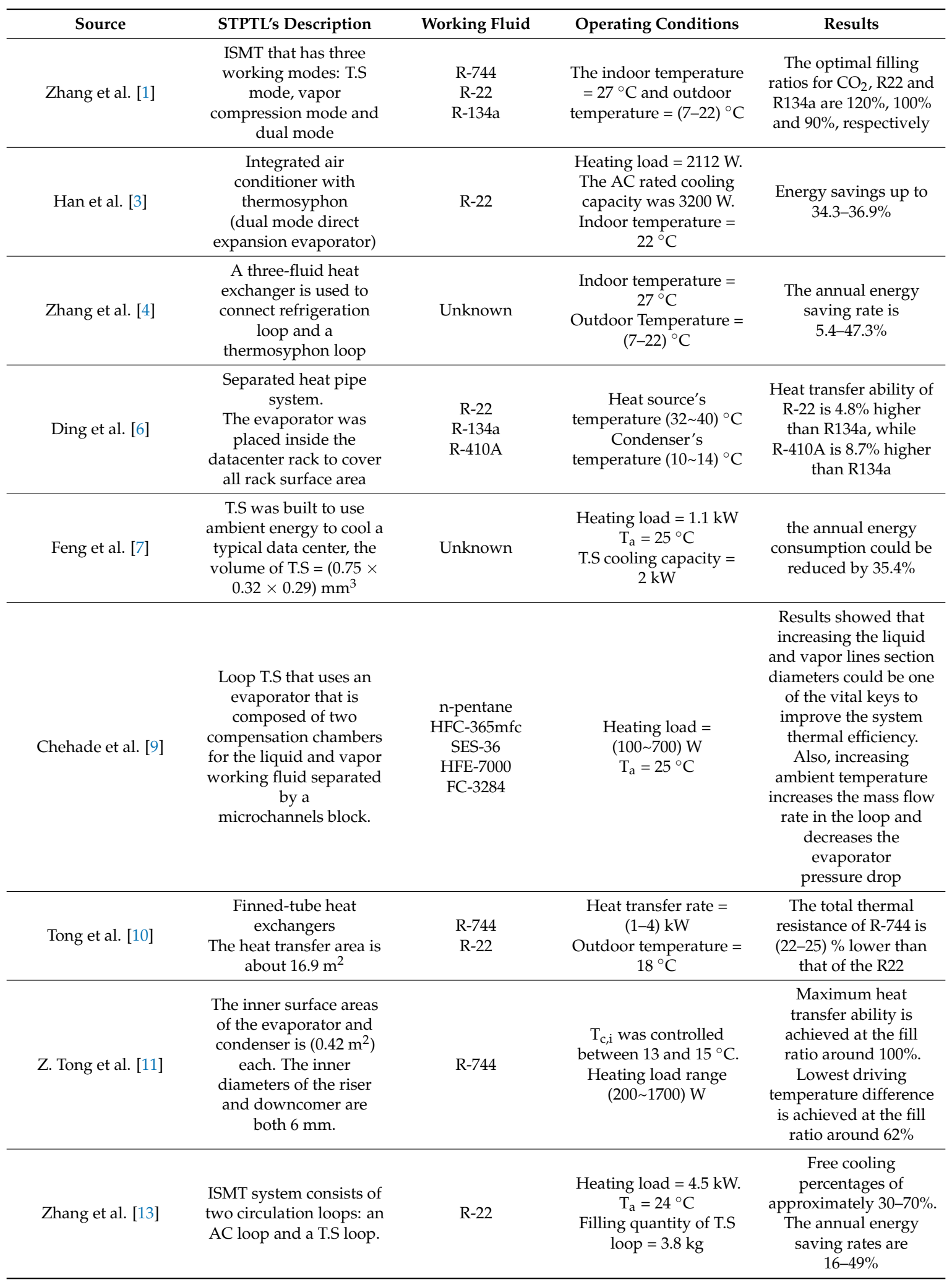


Table 1. Cont.

\begin{tabular}{|c|c|c|c|c|}
\hline Source & STPTL's Description & Working Fluid & Operating Conditions & Results \\
\hline Zhang et al. [14] & $\begin{array}{l}\text { A tube-fin three-fluid } \\
\text { heat exchanger and a } \\
\text { parallel flow evaporator }\end{array}$ & $\mathrm{R}-22$ & $\begin{array}{l}\text { The indoor and outdoor } \\
\text { temperature differences } \\
\text { are }(10,15 \text { and } 20){ }^{\circ} \mathrm{C}\end{array}$ & $\begin{array}{l}\text { Best cooling capacity } \\
\text { of thermosiphon mode } \\
\text { is } 7.1 \mathrm{~kW} \text { at } 20^{\circ} \mathrm{C} \\
\text { temperature difference }\end{array}$ \\
\hline Zhang et al. [15] & $\begin{array}{c}\text { Integrated air } \\
\text { conditioner combines } \\
\text { thermosyphon and } \\
\text { vapor compression into } \\
\text { one device }\end{array}$ & Water & $\begin{array}{c}\mathrm{T}_{\mathrm{a}}=24{ }^{\circ} \mathrm{C} \\
\text { Cooling capacity was up } \\
\text { to } 49.2 \mathrm{~kW}\end{array}$ & $\begin{array}{l}\text { The proposed system } \\
\text { can save } 33 \% \text { of the } \\
\text { energy consumed for } \\
\text { cooling, compared } \\
\text { with traditional system }\end{array}$ \\
\hline Ling et al. [16] & $\begin{array}{c}\text { A micro channel } \\
\text { separated heat pipe, } \\
\text { evaporator's volume } \\
(750 \times 780 \times 25) \mathrm{mm}^{3}\end{array}$ & $\mathrm{R}-22$ & $\begin{array}{c}\text { 1. Dry/wet bulb } \\
\text { Temperature }= \\
(13 / 7.3){ }^{\circ} \mathrm{C} \\
\text { 2. Dry/wet bulb } \\
\text { Temperature }=(8 / 3.4){ }^{\circ} \mathrm{C}\end{array}$ & $\begin{array}{l}\text { The optimal refrigerant } \\
\text { filling ratio was } \\
88-101 \% \text {. } \\
\text { Cooling capacity was } \\
\text { increased by } 138 \% \\
\text { when the temperature } \\
\text { difference between } \\
\text { indoor and the outdoor } \\
\text { increased from } 5^{\circ} \mathrm{C} \\
\text { to } 10^{\circ} \mathrm{C}\end{array}$ \\
\hline Zhang et al. [17] & $\begin{array}{c}\mathrm{CO}_{2} \text { loop thermosyphon } \\
\text { with microchannel } \\
\text { parallel-flow } \\
\text { heat exchangers }\end{array}$ & $\begin{array}{c}\text { R-744 } \\
\text { R-22 }\end{array}$ & $\begin{array}{l}\text { The indoor and outdoor } \\
\text { temperature difference is } \\
\qquad 10^{\circ} \mathrm{C}\end{array}$ & $\begin{array}{l}\text { The optimal filling } \\
\text { ratio of R-744 is } 150 \% \text {. } \\
\text { The heat transfer rate } \\
\text { and circulation flow } \\
\text { rate increased with } \\
\text { height difference }\end{array}$ \\
\hline
\end{tabular}

With reference to the aforementioned related literatures, it is obvious that most of recent studies had focused on the usage of the separated two-phase thermosiphon loop in association with the outdoor environments for cooling the data centers, lacking detailed quantitatively energy saving for the system. Moreover, the idea of placing the thermosiphon on the rear of the data center rack was rarely discussed. This idea was experimentally investigated by Ding et al. [6]. However, they focused on investigating heat transfer capability and the factors that may influence the heat transfer performance of the loop such as filling ratio and no quantitatatively energy savings were reported. As a consequence, the objective of this experimental study is to bridge the realization and the actual energy saving when a separated thermosiphon loop as a free cooling technique is adopted, and to investigate the feasibility of using PFA pipe as an adiabatic connection as far as mobility is concerned. Moreover, as depicted in Table 1, very rare studies were available concerning the use of R-134a in STPTL even though it is widely used in air-conditioning and refrigeration industry.

\section{Experimental Setup and Approach}

\subsection{STPTL's Working Principle}

The thermosiphon attached to the back of data center rack transfers energy from a heat source (data center rack) to a heat rejection section (shell and coil condenser) via natural circulation of the $\mathrm{R}-134 \mathrm{a}$ as the working fluid. The generated vapor moves from the evaporator through riser toward the condenser where it condenses thereafter and circulates back to evaporator through downcomer to complete circulation. The geometric configuration of the STPTL is arranged such that the condensed liquid can flow back to the evaporator by gravity as can be seen in Figure 2a.

\subsection{Introduction to the Experimental Setup}

Two identical datacenter racks have been installed in a small room. The size of the room is nearly $(3 \times 3 \times 3) \mathrm{m}^{3}$. Two electrical heaters were installed inside each rack. Both heaters reject a maximum heating load of $4 \mathrm{~kW}$ to the ambient. The size of each rack is $(0.6 \times 0.6 \times 1.95) \mathrm{m}^{3}$. The two racks were placed to face each other as shown in Figure 1a. An air conditioner (AC) having $14 \mathrm{~kW}$ cooling capacity 
was used as the main cooler for the racks. The AC was connected from the top with rectangular duct to transfer the cold air to a diffuser that was placed between the top of the two racks as shown in Figure 1. The cross-sectional area of the rectangular duct is $(0.3 \times 0.3) \mathrm{m}^{2}$. Also, each rack has an identical set of fans (15 fans each).

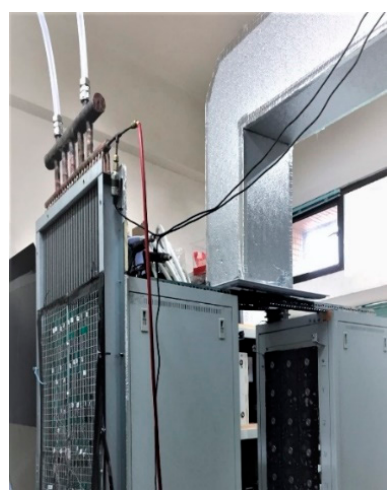

(a)

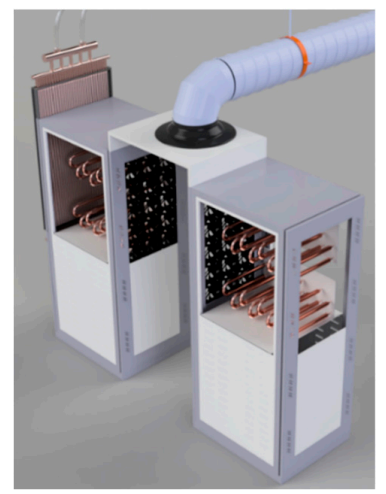

(b)

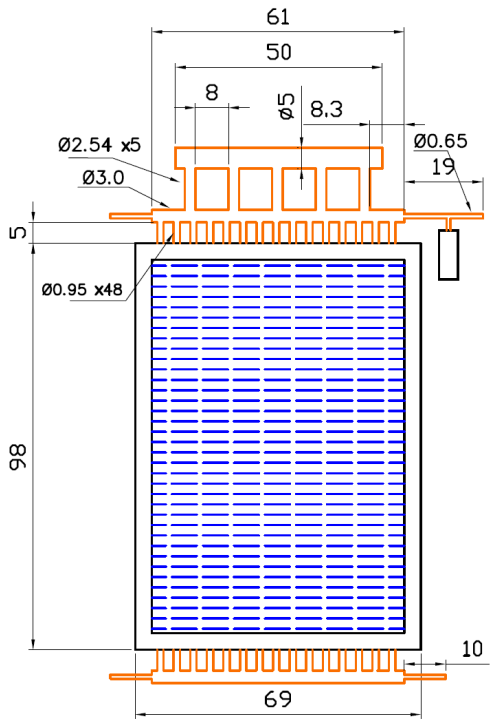

(c)

Figure 1. Datacenter racks' configuration: (a) A general view of datacenter racks arrangement with duct system; (b) 3D-modeling of the datacenter rack, it shows the position of heaters that simulate network servers; (c) Dimensions of the thermosiphon in $\mathrm{cm}$.

\subsection{Description of the STPTL}

A fin-and-tube thermosiphon heat exchanger made of copper pipes and aluminum fins was attached on the back of one of the racks. The surface area of the thermosiphon is $1.11 \times 0.69 \mathrm{~m}^{2}$ including collector and header, and it consists of 48 vertical copper tubes with $9.52 \mathrm{~mm}$ nominal diameter (10.3 mm collar diameter after expansion). The header of the thermosiphon consists of five copper pipes (1-inch diameter each) which are connected to another 2 inches diameter extended header as shown in Figure 2a to allow better vapor distribution and easier transmission to the condenser. The thermosiphon represents the evaporator of the STPTL, which was connected with the condenser by an adiabatic fluorothermo-plastic material pipes (PFA). The PFA serves as vapor line and liquid line. Two vapor lines of 2 inches diameter and about $2.2 \mathrm{~m}$ length were used for lowering transmission impedance to the condenser, whereas one liquid line of 2 inches diameter, $1.65 \mathrm{~m}$ length was installed, which is large enough for the condensed liquid to flow back via gravity to the evaporator. The condenser was placed at the highest point close to the ceiling, it should be higher than the thermosiphon to provide enough space for the condensed liquid to accumulate in the 
liquid line, this is quite essential especially at high filling ratios (e.g., $70 \%$ and $90 \%$ ) because the level of liquid is comparatively high (close to the condenser's outlet). The condenser is a simple water-cooled shell and coil heat exchanger, and it was designed to reject heating load up to $6 \mathrm{~kW}$. It consists of a 0.75 -inch diameter, $3.5 \mathrm{~m}$ length coiled copper pipe as shown schematically in Figure 2a. Chilled water is circulated in the coiled pipe, while the R-134a vapor is circulated in the annulus around the tube.

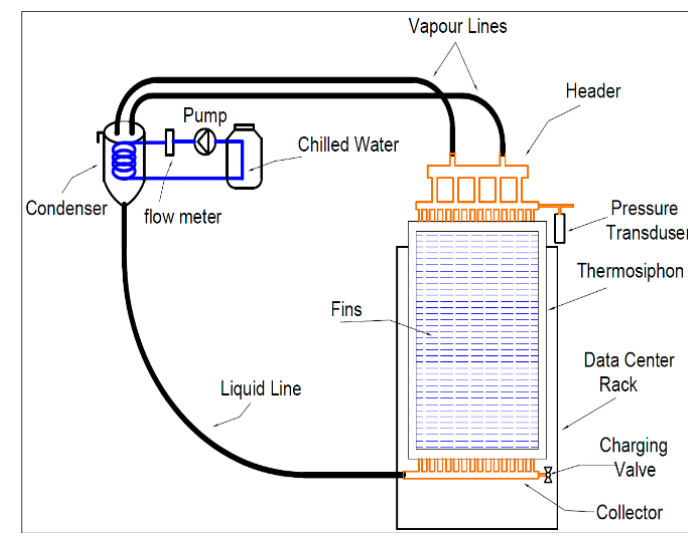

(a)

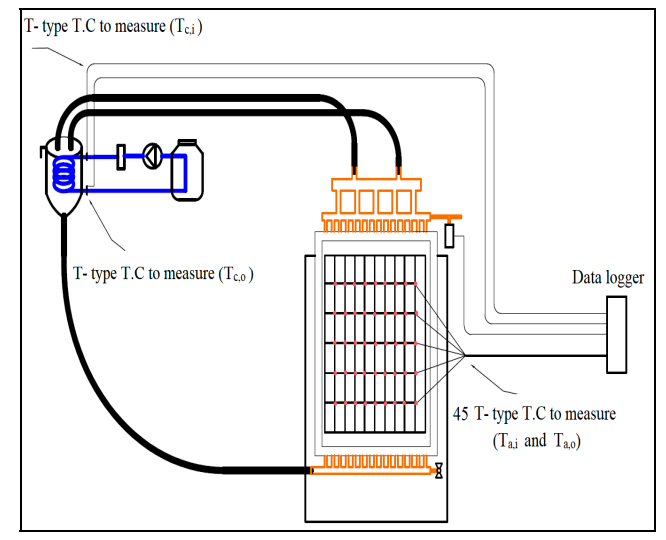

(b)

Figure 2. The schematic diagram of the experimental setup: (a) The components of the STPTL; (b) Measurements apparatus.

\subsection{Experimental Approach and Operating Conditions}

In order to obtain the desired results, the following parameters have been studied:

- Ambient air temperature $\left(\mathrm{T}_{\mathrm{a}}\right)$ : the experiment was conducted at three different ambient temperatures $\left(21^{\circ} \mathrm{C}, 23^{\circ} \mathrm{C}\right.$, and $\left.25^{\circ} \mathrm{C}\right)$.

- Chilled water's temperature $\left(\mathrm{T}_{\mathrm{C}}\right)$ : the experiment was conducted twice at two different temperatures, $\left(15^{\circ} \mathrm{C}\right.$ and $\left.20^{\circ} \mathrm{C}\right)$.

- Chilled water's flow rate: water flow rate was constant for all cases $(15 \mathrm{~L} / \mathrm{min})$.

- Filling ratio of R-134a: the experiment was conducted at five different filling ratios $(10 \%, 30 \%$, $50 \%, 70 \%$, and $90 \%$ ). The filling ratio is based on the volume of the evaporator.

- Heating Load: The experiment was conducted at a constant heating load (4 kW) with two heaters ( $2 \mathrm{~kW}$ each) being turned on for all experiment cases. See Figure $1 \mathrm{~b}$.

The experiment was conducted for all cases under the same conditions, and the total power consumption of cooling systems was compared and recorded then plotted for all the cases of the aforementioned parameters. More details about the experimental apparatus and operating conditions are explained in the following section.

\subsection{Experimental Apparatus and Measurements}

Fans were installed on the front door of each rack. Air velocity was measured by thermo-anemometer (LM-8000, Tecpel, Taipei, Taiwan), the measuring range of the device is (0.2 30) $\mathrm{m} / \mathrm{s}$ with precision of $0.1 \mathrm{~m} / \mathrm{s}$. Average air velocity for each set of fans was $2.5 \mathrm{~m} / \mathrm{s}$, PWM controllers were used to adjust the air velocity to be identical for both racks and it was kept the same for all cases. To find the power consumed by each set of fans, digital multimeter was used to measure voltage and current, thus, the calculated power was $66.48 \mathrm{~W}$. The inlet and outlet temperature of the rack were measured by using 45 T-type thermocouples (OMEGA, Singapore, Singapore), they were fixed and distributed evenly on a mesh as shown in Figure $2 b$. The mesh was fabricated to cover the whole fans area at the inlet and outlet $(0.7 \times 0.55) \mathrm{m}^{2}$. The obtained temperature values were used to calculate the average temperature of the evaporator $\left(\mathrm{T}_{\mathrm{e}, \mathrm{avg}}\right)$. In order to measure the average temperature of the condenser $\left(\mathrm{T}_{\mathrm{c}, \mathrm{avg}}\right)$, more $\mathrm{T}$-type thermocouples were installed at the inlet and the outlet of the pipe 
wall of the chill water as shown in Figure $2 \mathrm{~b}$. A rotameter flow meter was used to measure water flowrate in condenser, and its accuracy is $\pm 0.21 / \mathrm{min}$. All thermocouples were calibrated by RTD with an accuracy of $\pm 0.1^{\circ} \mathrm{C}$. The values of temperatures were obtained by using digital recorder (LR8400-20, HIOKI E. E., Nagano, Japan). The same data logger was used to measure the working pressure of R-134a at different filling ratios, the values were recorded by using (Yokogawa, Tokyo, Japan) type absolute pressure transducer which was connected with the header of the thermosiphon as shown in Figure $2 \mathrm{~b}$, the range of the device is $0 \sim 20 \mathrm{kgf} / \mathrm{cm}^{2}$, and the measurement uncertainty for voltage is $\pm 0.001 \mathrm{~V}$. The electrical power consumption was recorded for every case using WT210 digital power meter (Yokogawa, Tokyo, Japan), model number 760401, and its uncertainty is $\pm 0.1 \mathrm{~W}$. Experimental apparatus with the accuracy of each device are tabulated in Table 2.

Table 2. Measurements devices and their accuracy.

\begin{tabular}{ccc}
\hline Apparatus & Accuracy & Unit \\
\hline Anemometer (LM-8000) & \pm 0.1 & $\mathrm{~m} / \mathrm{s}$ \\
Digital multimeter & \pm 0.01 & $\mathrm{~V}, \mathrm{~A}$ \\
Thermocouple (T-Type) & \pm 0.1 & ${ }^{\circ} \mathrm{C}$ \\
Rotameter flow meter & \pm 0.2 & $1 / \mathrm{min}$ \\
Pressure transducer & \pm 0.001 & $\mathrm{~V}$ \\
Digital power meter & \pm 0.1 & $\mathrm{~W}$ \\
\hline
\end{tabular}

\section{Data Reduction}

A comparative experiment was performed to validate the effectiveness of the STPTL. The experiment started with testing the traditional datacenter rack (with no thermosiphon). Electrical power consumed by AC $\left(\mathrm{P}_{\mathrm{ac}}\right)$, the inlet air temperature $\left(\mathrm{T}_{\mathrm{ai}}\right)$, and outlet air temperature $\left(\mathrm{T}_{\mathrm{ao}}\right)$ of the datacenter rack were recorded then compared with the results of the other rack that is combined with the STPTL. The performance of STPTL was investigated at different filling ratios of the working fluid $(10 \%, 30 \%, 50 \%, 70 \%$, and $90 \%)$. The filling ratio is defined by the following Equation:

$$
\mathrm{FR} \%=\frac{\mathrm{v}_{1}}{\mathrm{~V}_{\mathrm{e}}}
$$

where $V_{1}$ is the R-134a liquid volume and $V_{e}$ is the volume of the evaporator. Best performance of the loop can be obtained through the longest relief of compressor running time of the air-conditioning system where maximum energy savings can be obtained.

\subsection{Power Consumed by the Rack with No Thermosiphon}

While measuring the inlet and outlet air temperature at front and back door of the rack, power meter recording the power consumption of the AC within specific period of time ( $30 \mathrm{~min}$ ) was adopted for all cases. Power of fans was calculated by multiplying the supply voltage and the current which were measured by the multi-meter, namely

$$
\mathrm{P}_{\mathrm{f}}=\mathrm{V} \times \mathrm{I}
$$

where $\mathrm{P}_{\mathrm{f}}$ is the total power consumed by the ( 15 fans). Thus, total power consumption of the traditional rack $\left(\mathrm{P}_{\mathrm{tr}}\right)$ is the summation of power consumed by fans and $\mathrm{AC}$, i.e.,

$$
\mathrm{P}_{\mathrm{tr}}=\mathrm{P}_{\mathrm{ac}}+\mathrm{P}_{\mathrm{f}}
$$

\subsection{Power Consumed by the Rack with the Thermosiphon Loop STPTL}

In addition to the power consumed by fans and AC, power consumed by condenser's chilled water should be added. Accordingly, total power consumed by the rack with thermosiphon can be calculated such that, 


$$
\mathrm{Pt}=\mathrm{P}_{\mathrm{ac}}+\mathrm{P}_{\mathrm{f}}+\mathrm{P}_{\mathrm{ch}}+\mathrm{P}_{\mathrm{p}}
$$

where, $\mathrm{P}_{\mathrm{ch}}$ is the power consumed by chiller and $\mathrm{P}_{\mathrm{p}}$ is the power consumed by the pump. In order to calculate $\mathrm{P}_{\mathrm{ch}}$, the amount of heat removed at the condenser has to be known, it can be determined by the energy balance equation:

$$
\mathrm{Q}_{\mathrm{c}}=\dot{\mathrm{m}}_{\mathrm{wa}} \times \mathrm{C}_{\mathrm{wa}}\left(\mathrm{T}_{\mathrm{c}, \mathrm{o}}-\mathrm{T}_{\mathrm{c}, \mathrm{i}}\right)
$$

where $T_{c, i}$ and $T_{c, o}$ are the inlet and outlet temperatures of the condenser, respectively. Then, $P_{c h}$ can be calculated by dividing chilled water's cooling capacity on the coefficient of performance of the chiller as follows:

$$
\mathrm{P}_{\mathrm{ch}}=\frac{\mathrm{Q}_{\mathrm{c}}}{\mathrm{COP}}
$$

where COP being chiller's coefficient of performance and it is equal to 4.2 .

The liquid pump's electrical consumption at a specific flow rate $(15 \mathrm{l} / \mathrm{min})$ is approximately equal to $60 \mathrm{~W}$. The saving of energy subject to saving's percentage was calculated such that,

$$
\text { E.S }=\left[1-\left(\frac{P_{t}}{P_{\text {tr }}}\right)\right] \times 100 \%
$$

Uncertainty analysis regarding power consumption calculations are tabulated in Table 3.

Table 3. Uncertainty analysis regarding power consumption calculations.

\begin{tabular}{ccc}
\hline & \multicolumn{1}{c}{ Equation } & Uncertainty \\
\hline $\mathrm{P}_{\mathrm{f}}$ & $\frac{\delta\left(\mathrm{P}_{\mathrm{f}}\right)}{\mathrm{P}_{\mathrm{f}}}=\sqrt{\left(\frac{\delta(\mathrm{V})}{\mathrm{V}}\right)^{2}+\left(\frac{\delta(\mathrm{I})}{\mathrm{I}}\right)^{2}}$ & $0.136 \mathrm{~W}$ \\
\hline $\mathrm{P}_{\mathrm{tr}}$ & $\delta\left(\mathrm{P}_{\mathrm{tr}}\right)=\sqrt{\left(\delta \mathrm{P}_{\mathrm{f}}\right)^{2}+\left(\delta \mathrm{P}_{\mathrm{ac}}\right)^{2}}$ & $0.169 \mathrm{~W}$ \\
\hline $\mathrm{Q}_{\mathrm{c}}$ & $\frac{\delta\left(\mathrm{Q}_{\mathrm{c}}\right)}{\mathrm{Q}_{\mathrm{c}}}=\sqrt{\left(\frac{\delta(\mathrm{V})}{\mathrm{V}}\right)^{2}+\left(\frac{\delta(\mathrm{T})}{\mathrm{T}}\right)^{2}}$ & $(11.49 \sim 24.15) \mathrm{W}$ \\
\hline $\mathrm{P}_{\mathrm{t}}$ & $\delta\left(\mathrm{P}_{\mathrm{t}}\right)=\sqrt{\left(\delta \mathrm{P}_{\text {tr }}\right)^{2}+\left(\delta \mathrm{P}_{\mathrm{f}}\right)^{2}+\left(\delta \mathrm{P}_{\mathrm{ac}}\right)^{2}}$ & $(25.51 \sim 55.88) \mathrm{W}$ \\
\hline
\end{tabular}

\section{Results and Discussion}

\subsection{Power Consumption and Energy Savings Results}

The experiment was conducted subject to three ambient temperatures $\left(21^{\circ} \mathrm{C}, 23^{\circ} \mathrm{C}\right.$, and $25^{\circ} \mathrm{C}$, respectively) in association with filling ratio ranging from 10 90\%. The power consumptions for $\mathrm{P}_{\mathrm{ac}}$, $\mathrm{P}_{\mathrm{f}}, \mathrm{P}_{\mathrm{ch}}$, and $\mathrm{P}_{\mathrm{p}}$, are tabulated in Tables 4 and 5 for $\mathrm{T}_{\mathrm{c}, \mathrm{i}}=15^{\circ} \mathrm{C}$ and $20^{\circ} \mathrm{C}$, respectively. Figure $3 \mathrm{a}, \mathrm{b}$ show the measured power consumption at steady state as a function of filling ratios. Yet the typical outlet temperature of the data rack is schematically shown in Figure 4.

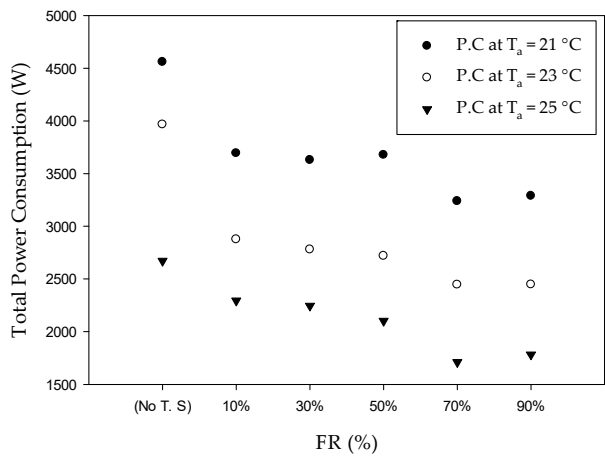

(a)

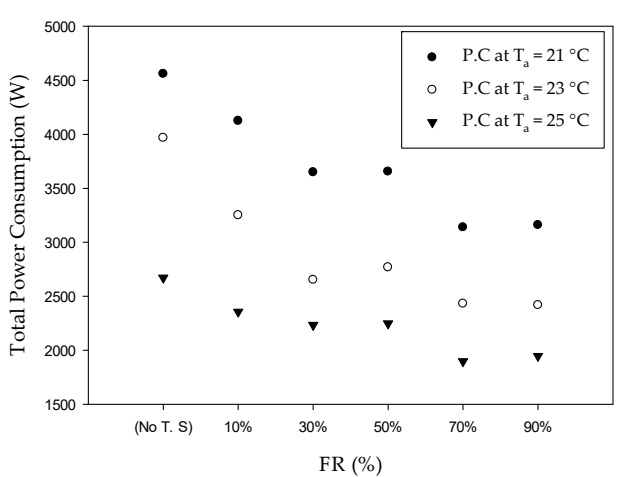

(b)

Figure 3. Cont. 


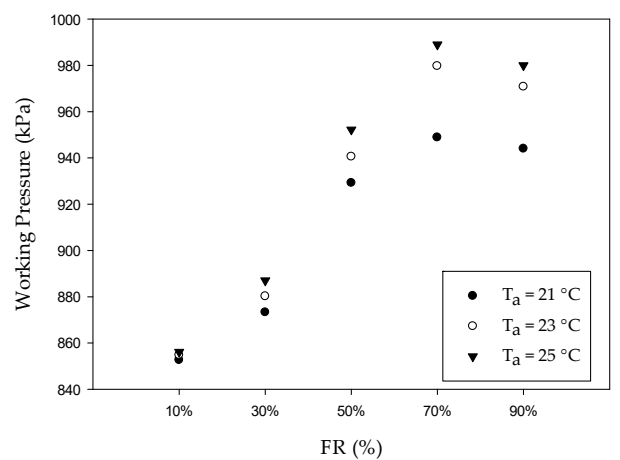

(c)

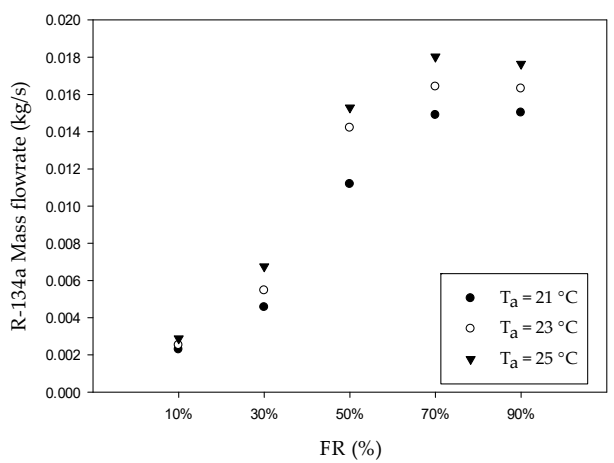

(d)

Figure 3. Total power consumed by the cooling system and the corresponding working pressure and mass flow rate of working fluid at different filling ratios: (a) Case (1), total power consumption when $\mathrm{T}_{\mathrm{c}, \mathrm{i}}=15^{\circ} \mathrm{C}$; (b) Case (2), total power consumption when $\mathrm{T}_{\mathrm{c}, \mathrm{i}}=20^{\circ} \mathrm{C}$; (c) Working pressure at different filling ratios when $\mathrm{T}_{\mathrm{c}, \mathrm{i}}=15^{\circ} \mathrm{C}$; (d) Mass flowrate of $\mathrm{R}-134 \mathrm{a}$ at different filling ratios when $\mathrm{T}_{\mathrm{c}, \mathrm{i}}=15^{\circ} \mathrm{C}$.

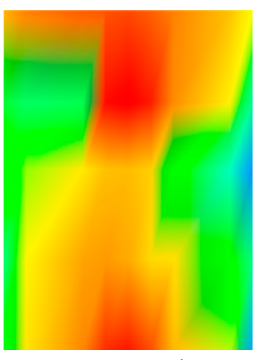

$\mathrm{FR}=10 \%$

$\mathrm{Ta}=21^{\circ} \mathrm{C}$

$\mathrm{Tc}, \mathrm{i}=20^{\circ} \mathrm{C}$

$\mathrm{SD}=5.24^{\circ} \mathrm{C}$

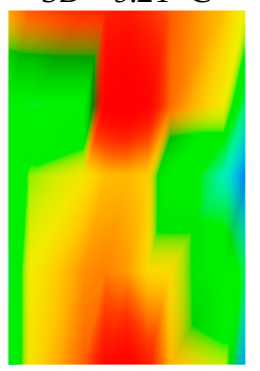

$\mathrm{FR}=10 \%$

$\mathrm{Ta}=23^{\circ} \mathrm{C}$

$\mathrm{Tc}, \mathrm{i}=20^{\circ} \mathrm{C}$

$\mathrm{SD}=5.52^{\circ} \mathrm{C}$

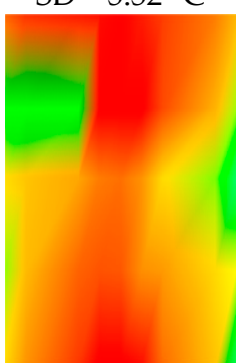

$\mathrm{FR}=10 \%$

$\mathrm{Ta}=25^{\circ} \mathrm{C}$

$\mathrm{Tc}, \mathrm{i}=20^{\circ} \mathrm{C}$

$\mathrm{SD}=5.49^{\circ} \mathrm{C}$

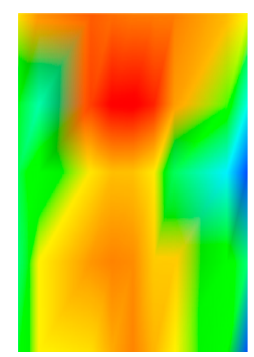

$\mathrm{FR}=30 \%$

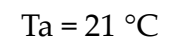

Tc, $\mathrm{i}=20^{\circ} \mathrm{C}$

$\mathrm{SD}=5.10^{\circ} \mathrm{C}$

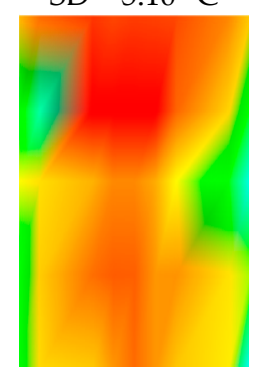

$\mathrm{FR}=30 \%$

$\mathrm{Ta}=23^{\circ} \mathrm{C}$

$\mathrm{Tc}, \mathrm{i}=20^{\circ} \mathrm{C}$

$\mathrm{SD}=5.22^{\circ} \mathrm{C}$

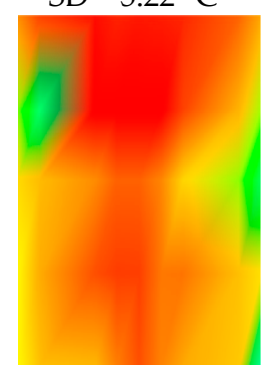

$\mathrm{FR}=30 \%$

$\mathrm{Ta}=25^{\circ} \mathrm{C}$

$\mathrm{Tc}, \mathrm{i}=20^{\circ} \mathrm{C}$

$\mathrm{SD}=5.27^{\circ} \mathrm{C}$

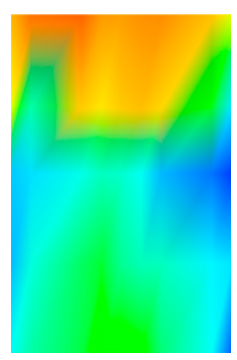

$\mathrm{FR}=50 \%$

$\mathrm{Ta}=21^{\circ} \mathrm{C}$

$\mathrm{Tc}, \mathrm{i}=20^{\circ} \mathrm{C}$

$\mathrm{SD}=4.38^{\circ} \mathrm{C}$

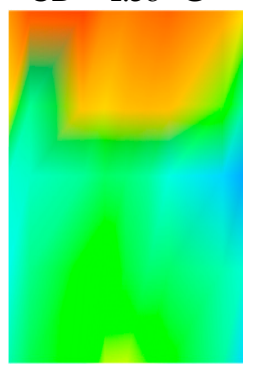

$\mathrm{FR}=50 \%$

$\mathrm{Ta}=23^{\circ} \mathrm{C}$

$\mathrm{Tc}, \mathrm{i}=20^{\circ} \mathrm{C}$

$\mathrm{SD}=4.43^{\circ} \mathrm{C}$

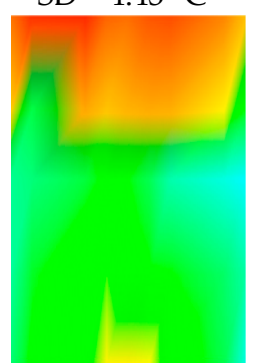

$\mathrm{FR}=50 \%$

$\mathrm{Ta}=25^{\circ} \mathrm{C}$

$\mathrm{Tc}, \mathrm{i}=20^{\circ} \mathrm{C}$

$\mathrm{SD}=4.55^{\circ} \mathrm{C}$

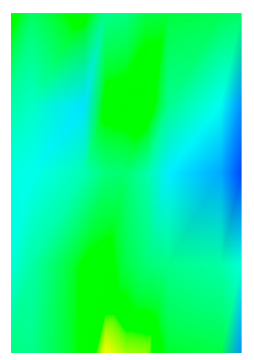

$\mathrm{FR}=70 \%$

$\mathrm{Ta}=21^{\circ} \mathrm{C}$

$\mathrm{Tc}, \mathrm{i}=20^{\circ} \mathrm{C}$

$\mathrm{SD}=1.72^{\circ} \mathrm{C}$

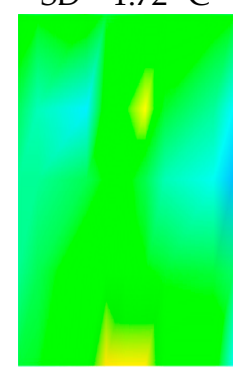

$\mathrm{FR}=70 \%$

$\mathrm{Ta}=23^{\circ} \mathrm{C}$

$\mathrm{Tc}, \mathrm{i}=20^{\circ} \mathrm{C}$

$\mathrm{SD}=1.65^{\circ} \mathrm{C}$

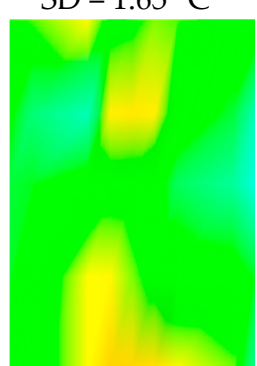

$\mathrm{FR}=70 \%$

$\mathrm{Ta}=25^{\circ} \mathrm{C}$

$\mathrm{Tc}, \mathrm{i}=20^{\circ} \mathrm{C}$

$\mathrm{SD}=1.63^{\circ} \mathrm{C}$

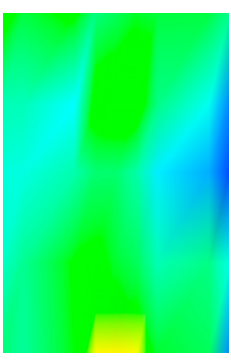

$\mathrm{FR}=90 \%$

$\mathrm{Ta}=21^{\circ} \mathrm{C}$

$\mathrm{Tc}, \mathrm{i}=20^{\circ} \mathrm{C}$

$\mathrm{SD}=2.87^{\circ} \mathrm{C}$

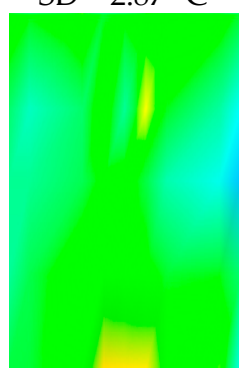

$\mathrm{FR}=90 \%$

$\mathrm{Ta}=23^{\circ} \mathrm{C}$

$\mathrm{Tc}, \mathrm{i}=20^{\circ} \mathrm{C}$

$\mathrm{SD}=2.37^{\circ} \mathrm{C}$

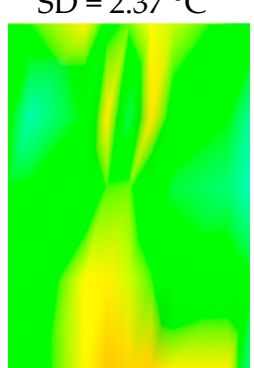

$\mathrm{FR}=90 \%$

$\mathrm{Ta}=25^{\circ} \mathrm{C}$

$\mathrm{Tc}, \mathrm{i}=20^{\circ} \mathrm{C}$

$\mathrm{SD}=1.64^{\circ} \mathrm{C}$

Figure 4. Racks' outlet temperature distribution $\left(\mathrm{T}_{\mathrm{c}, \mathrm{i}}=20^{\circ} \mathrm{C}\right)$. 
In Figure 3, the test results showed that the performance of the STPTL is improved with the rise of filling ratios and the maximum energy saving occurs at a filling ratio of $70 \%$, and a further increase of the filling ratio to $90 \%$ leads to a moderate decline of energy saving. At a low filling ratio such as $10 \%$ and $30 \%$, despite some energy saving is still achievable for such low filling ratios, the uneven high outlet temperatures as shown in Figure 4 implicates that the low filling ratios cannot effectively provide a temperature uniformity, the standard deviation of the temperature variation of airflow at the outlet of thermosiphon heat exchanger is as high as $5.52{ }^{\circ} \mathrm{C}$. Details about energy saving percentage are explained in Tables 4 and 5. Notice that percentage of energy savings can reach up to $33.2 \%$ in one of $30 \%$ filling ratio cases.

Table 4. Energy consumption and energy savings details at $\mathrm{T}_{\mathrm{c}, \mathrm{i}}=15^{\circ} \mathrm{C}$.

\begin{tabular}{cccccccc}
\hline $\mathbf{T}_{\mathbf{a}}\left({ }^{\circ} \mathbf{C}\right)$ & All Cases & $\mathbf{P}_{\mathbf{a c}}(\mathbf{W})$ & $\mathbf{P}_{\mathbf{c h}}(\mathbf{W})$ & $\mathbf{P}_{\mathbf{f}}(\mathbf{W})$ & $\mathbf{P}_{\mathbf{p}}(\mathbf{W})$ & $\mathbf{P}_{\mathbf{t}}(\mathbf{W})$ & E.S $(\%)$ \\
\hline \multirow{5}{*}{21} & (No T.S) & 4493.7 & 0.0 & 66.48 & 0 & 4560.2 & 0.0 \\
& FR (10\%) & 3338.0 & 230.0 & 66.48 & 60 & 3694.5 & 19.0 \\
& FR (30\%) & 3085.8 & 417.7 & 66.48 & 60 & 3630.0 & 20.4 \\
& FR (50\%) & 3025.3 & 526.6 & 66.48 & 60 & 3678.4 & 19.3 \\
& FR (70\%) & 2520.8 & 592.9 & 66.48 & 60 & 3240.2 & 28.9 \\
& FR (90\%) & 2478.8 & 684.5 & 66.48 & 60 & 3289.8 & 27.9 \\
\hline \multirow{2}{*}{23} & (No T.S) & 3901.0 & 0.0 & 66.48 & 0 & 3967.4 & 0.0 \\
& FR (10\%) & 2606.0 & 142.9 & 66.48 & 60 & 2875.3 & 27.5 \\
& FR (30\%) & 2483.1 & 171.4 & 66.48 & 60 & 2781.0 & 29.9 \\
& FR (50\%) & 2317.1 & 276.2 & 66.48 & 60 & 2719.8 & 31.4 \\
& FR (70\%) & 1933.4 & 385.7 & 66.48 & 60 & 2445.6 & 38.4 \\
& FR (90\%) & 1873.6 & 447.6 & 66.48 & 60 & 2447.7 & 38.3 \\
\hline \multirow{2}{*}{25} & (No T.S) & 2604.6 & 0.0 & 66.48 & 0 & 2671.0 & 0.0 \\
& FR (10\%) & 2068.6 & 99.2 & 66.48 & 60 & 2294.3 & 14.1 \\
& FR (30\%) & 1913.7 & 205.5 & 66.48 & 60 & 2245.7 & 15.9 \\
& FR (50\%) & 1733.6 & 241.9 & 66.48 & 60 & 2102.0 & 21.3 \\
& FR (70\%) & 1373.6 & 211.2 & 66.48 & 60 & 1711.3 & 35.9 \\
& FR (90\%) & 1371.2 & 285.7 & 66.48 & 60 & 1783.4 & 33.2 \\
\hline
\end{tabular}

Table 5. Energy consumption and energy savings details at $\mathrm{T}_{\mathrm{c}, \mathrm{i}}=20^{\circ} \mathrm{C}$.

\begin{tabular}{cccccccc}
\hline $\mathbf{T}_{\mathbf{a}}\left({ }^{\circ} \mathbf{C}\right)$ & All Cases & $\mathbf{P}_{\mathbf{a c}}(\mathbf{W})$ & $\mathbf{P}_{\mathbf{c h}}(\mathbf{W})$ & $\mathbf{P}_{\mathbf{f}}(\mathbf{W})$ & $\mathbf{P}_{\mathbf{p}}(\mathbf{W})$ & $\mathbf{P}_{\mathbf{t}}(\mathbf{W})$ & E.S (\%) \\
\hline \multirow{5}{*}{21} & (No T.S) & 4493.7 & 0.0 & 66.48 & 0 & 4560.2 & 0.0 \\
& FR (10\%) & 3830.7 & 166.7 & 66.48 & 60 & 4123.8 & 9.6 \\
& FR (30\%) & 3153.4 & 369.0 & 66.48 & 60 & 3648.9 & 20.0 \\
& FR (50\%) & 3147.9 & 381.0 & 66.48 & 60 & 3655.3 & 19.8 \\
& FR (70\%) & 2601.8 & 409.8 & 66.48 & 60 & 3138.0 & 31.2 \\
& FR (90\%) & 2559.8 & 473.8 & 66.48 & 60 & 3160.1 & 30.7 \\
\hline \multirow{2}{*}{23} & (No T.S) & 3901.0 & 0.0 & 66.48 & 0 & 3967.4 & 0.0 \\
& FR (10\%) & 3005.7 & 119.0 & 66.48 & 60 & 3251.2 & 18.1 \\
& FR (30\%) & 2358.3 & 166.7 & 66.48 & 60 & 2651.5 & 33.2 \\
& FR (50\%) & 2450.0 & 190.5 & 66.48 & 60 & 2766.9 & 30.3 \\
& FR (70\%) & 2066.2 & 238.1 & 66.48 & 60 & 2430.8 & 38.7 \\
& FR (90\%) & 2039.3 & 285.7 & 66.48 & 60 & 2451.5 & 38.2 \\
\hline \multirow{2}{*}{ 25 } & (No T.S) & 2604.6 & 0.0 & 66.48 & 0 & 2671.0 & 0.0 \\
& FR (10\%) & 2148.5 & 81.0 & 66.48 & 60 & 2355.9 & 11.8 \\
& FR (30\%) & 1981.3 & 125.2 & 66.48 & 60 & 2233.0 & 16.4 \\
& FR (50\%) & 1964.9 & 156.2 & 66.48 & 60 & 2247.6 & 15.9 \\
& FR (70\%) & 1604.9 & 166.7 & 66.48 & 60 & 1898.1 & 28.9 \\
& FR (90\%) & 1617.4 & 202.4 & 66.48 & 60 & 1946.2 & 27.1 \\
\hline
\end{tabular}

As shown in Tables 4 and 5, the best power consumption was obtained at filling ratio of $70 \%$ where the energy savings is as high as $38.7 \%$. This is because the evaporator is fully flooded with such filling ratio, and the evaporator can fulfill effective evaporation. Yet the yielded higher pressure with such high filling ratios also ensure circulating more working fluid across the circuitry as shown in Figure $3 c$, since the flowrate also increases with the rising pressure. Figure $3 d$ depicts the working 
fluid's flowrate at different filling ratios. This can also make clear from the temperature contour at the outlet of data rack as seen in Figure 4 where the temperature uniformity is almost attainable when the filling ratio exceeds $70 \%$. However, a further increase of filling ratio to $90 \%$, result in a slightly reduction of energy saving as compared to the filling ratio of $70 \%$. The results indicate that there is no extra energy saving benefit when the filling ratio exceeds the fully flooded condition of the evaporator. Hence, increasing filling ratio beyond fully flooding is actually not helping as far as energy saving is concerned, indicating overfilling might lead to degradation in heat transfer rate. This can be elaborated from the pressure measurement as depicted in Figure $3 \mathrm{c}$ where the system pressure for $90 \%$ filling ratio is slightly lower (about $10 \mathrm{kPa}$ less) than a filling ratio of $70 \%$. The energy saving is actually in line with the system pressure, and the maximum energy saving (70\%) occurs at the maximum system pressure. Note that the system pressure is gradually increased from about $855 \mathrm{kPa}$ to $990 \mathrm{kPa}$ while the filling ratio ranges from $10 \sim 70 \%$. The results reveal a plateau at an optimum filling ratio near $70 \%$. The system pressure then drops about $10 \mathrm{kPa}$ when the filling ratio is further raised to $90 \%$. To explain this phenomenon, one would need to understand the phase change process of the thermosiphon at the present constant heating load condition. For a low filling ratio of $10-30 \%$, the evaporator can be divided into two portions, the lower part of thermosiphon is the boiling zone while the upper part of the thermosiphon is simply a superheated zone, and the schematic of the low filling ratio can be depicted in Figure 5a. The level of the working fluid in these cases could not exceed $0.22 \mathrm{~m}$ height in the STPTL. The under-filling situation starves the evaporator, thereby leading to a higher uneven temperature distribution especially at the upper part of the thermosiphon heat exchanger as shown in Figure 4 . Thereby, the cooling capacity and circulation flowrate will be decreased. With continuous rise of filling ratio from $10 \%$ to $70 \%$, the system pressure also increases accordingly and the flow inside the evaporator may become fully flooded at a filling ratio near $70 \%$ with the lower part being the boiling zone while the upper part being evaporation zone as schematically seen in Figure 5b. Boiling of the refrigerant at the lower part generates appreciable amount of vapor flow that brings the liquid entrainment toward the upper part of the thermosiphon that eventually hits and retains on the upper periphery of the thermosiphon by vapor flow, thus resulting in a film like structure, hence the heat transfer mode at the upper part is via evaporation rather than the boiling mode at the lower portion. The simultaneous presence of evaporation regime and boiling zone in a typical closed thermosiphon was first reported by [18] who experimentally reported geyser boiling in a vertical annular two-phase closed thermosiphon. A schematic about the geyser boiling is shown in Figure 6 by Khazaee et al. [19]. As seen in the figure, small bubbles are generated from the nucleate boiling zone, followed by growing size to the diameter of the thermosiphon tube. The vapor plugs then pushes the liquid slug upwards and eventually breaks up to spread around the tube periphery to yield annular flow zone as depicted in Figure 5b. This phenomenon was also numerically verified by Jouhara et al. [20].

In this range with filling ratios from $10 \%$ to $70 \%$, a continuous rise of vapor fraction through phase change via boiling or evaporation can effectively expand the vapor volume pronouncedly, therefore leading to a rise of system pressure. On the other hand, when the filling ratio is increased to $90 \%$ where the evaporator is in a state of overfilling as seen in Figure 5c. In this case, the evaporator is simply contained with a single boiling zone. The overfilling into the evaporator will not induce more vapor volume since the total heat input still maintains the same. Instead, it will reduce the mean vapor quality at the evaporator. Figure 7 shows the levels of liquid in evaporator and condenser at different filling ratios subject to no heat inputs, it is obvious that the liquid level of $90 \%$ FR exceeds the height of the rack. As a consequence, part of the liquid does not expose to the hot air. Note that the boiling heat transfer coefficient is normally higher than the evaporation heat transfer coefficient. This is normally the case in the present thermosiphon design for the vapor velocity is comparatively low. Notice that the present thermosiphon design is a passive device which differs greatly from active designs (forced convective boiling via compressor or pump). In essence, effect of nucleate boiling may surpass the influence of convective evaporation. The results indicate the effective heat transfer coefficient for the $90 \%$ filling ratio is higher than that of filling ratio of $70 \%$. Based on a simple relation 
of Newton's cooling law where $\mathrm{Q}=\mathrm{hA}\left(\mathrm{T}_{\mathrm{w}}-\mathrm{T}_{\text {sat }}\right)$, where $\mathrm{h}$ is the heat transfer coefficient, $\mathrm{T}_{\mathrm{w}}$ is the surface temperature and $T_{\text {sat }}$ is the saturation temperature. The corresponding saturation temperature must be reduced due to a higher boiling heat transfer coefficient for a filling ratio of $90 \%$. In this regard, the corresponding system pressure is slightly decreased with a filling ratio of $90 \%$.

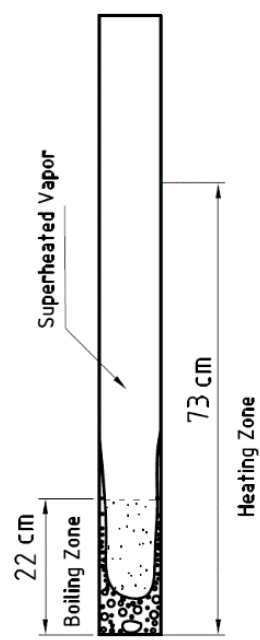

(a) $F R=30 \%$

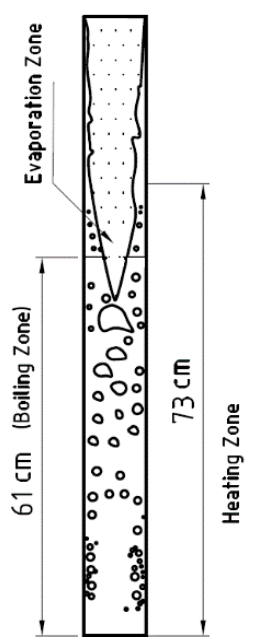

(b) $F R=70 \%$

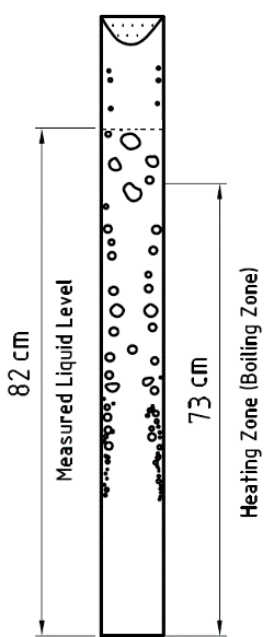

(c) $\mathrm{FR}=90 \%$

Figure 5. Schematic of the pool boiling process subject to different filling ratios.

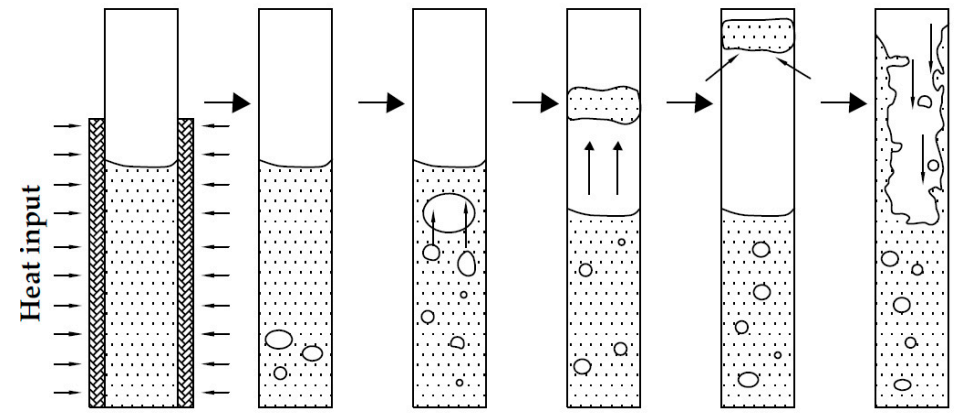

Figure 6. A schematic presentation about geyser boiling in a closed thermosiphon [19].

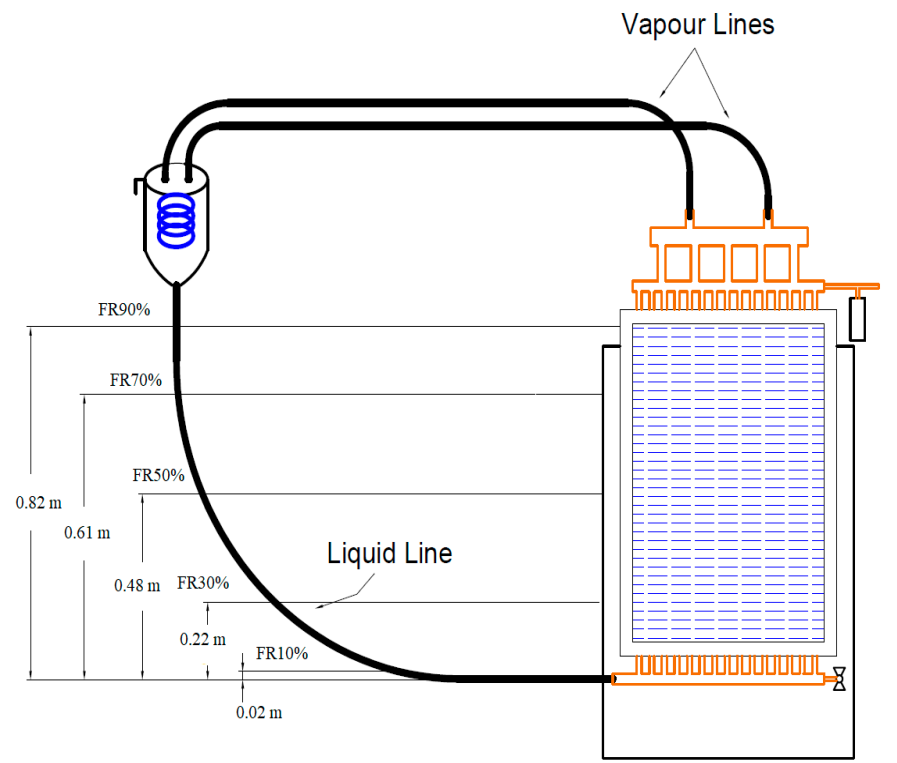

Figure 7. Liquid levels in the STPTL for different filling ratios. 


\subsection{Thermal Resistance of the STPTL Calculations and Results}

For further elaboration of the performance of thermosiphon heat exchanger, performance was investigated in terms of thermal resistance of the STPTL. The heat dissipation from the heater is regarded as $Q$ and 45 thermocouples were used to measure the average air inlet temperature $\left(T_{a i}\right)$ and outlet temperature $\left(\mathrm{T}_{\mathrm{ao}}\right)$, and some other thermocouples were used to measure the average temperature ( $\mathrm{T}_{\mathrm{c}, \mathrm{avg}}$ ) of the condenser. As mentioned earlier, the experiment was conducted at constant heating load $(4 \mathrm{~kW})$. However, the actual heat absorbed by the thermosiphon varies with operating conditions, such as rack inlet temperature (ambient temperature) and filling ratio. As depicted in Figure 8, there is no direct contact between heaters and thermosiphon, yet; the amount of heat transferred to the evaporator depends on the temperature in-between the heaters and thermosiphon $\left(\mathrm{T}_{\mathrm{h}}\right)$. Hence, heaters' temperature can be calculated as:

$$
\mathrm{T}_{\mathrm{h}}=\frac{\mathrm{Q}_{\mathrm{H}}}{\dot{\mathrm{m}}_{\mathrm{a} 1 \mathrm{cp}}}+\mathrm{T}_{\mathrm{ai}}
$$

where $Q_{H}$ represents the heaters' power into the data rack. As can be seen in Figure 8, air temperature and air flowrate changed after exiting the thermosiphon. Accordingly, the amount of heat absorbed by the thermosiphon can be calculated as,

$$
\mathrm{Q}=\dot{\mathrm{m}}_{\mathrm{a} 2} \mathrm{Cp}_{\mathrm{a}}\left(\mathrm{T}_{\mathrm{ao}}-\mathrm{T}_{\mathrm{h}}\right)
$$

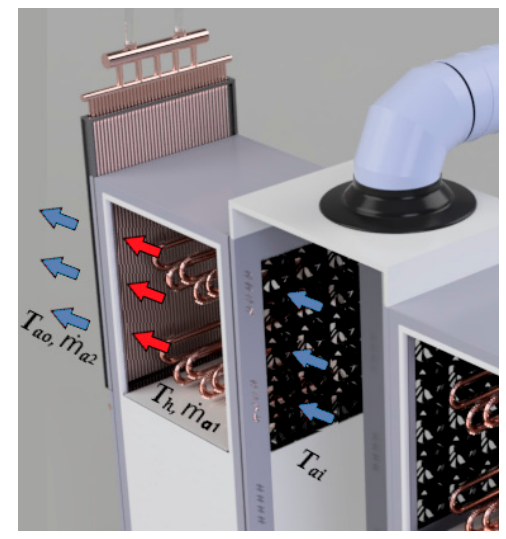

Figure 8. Changes of air temperature and flow rate during experiment.

The average temperature of evaporator was measured at the surface, then experimental overall thermal resistance can be calculated as,

$$
\mathrm{R}_{\mathrm{th}, \exp }=\frac{\left(\mathrm{T}_{\mathrm{e}, \mathrm{avg}}-\mathrm{T}_{\mathrm{c}, \text { avg }}\right)}{\mathrm{Q}}
$$

The overall thermal resistance is plotted in Figure 9 as a function of filling ratios. The results showed that lower thermal resistance occurs at high filling ratios (70\% and $90 \%)$ and at a higher ambient temperature. Correspondingly, the boiling heat transfer coefficient is higher at high filling ratios. This is because the corresponding boiling heat transfer coefficient is increased with the system pressure. Conversely, the condensation heat transfer coefficient decreases with the rise of pressure. In a typical thermosiphon, the increase of boiling heat transfer coefficient is always higher than the decline in condensation heat transfer coefficient, this can be made clear through some typical correlations applicable for boiling and condensation, e.g., Equations (11) and (12). In essence, a slight reduction in overall thermal resistance is seen with the rise of ambient temperature. To validate the experimental data of overall thermal resistance, some empirical correlations can be used to predict pool boiling and film condensation heat transfer coefficients are made. For current study, The correlations for estimating the boiling heat transfer coefficient in a thermosphion by Imura et al. [21] has been chosen to predict 
pool boiling heat transfer coefficient $\left(h_{b}\right)$, while Nusselt's theory of film condensation on a vertical flat plate can be applied to predict the average heat transfer coefficient of the nucleate liquid film boiling $\left(h_{\mathrm{co}}\right)[22]$, these correlations are as follows:

$$
\begin{gathered}
\mathrm{h}_{\mathrm{b}}=0.32\left(\frac{\rho_{\mathrm{l}}^{0.65} \mathrm{k}_{\mathrm{l}}^{0.3} \mathrm{C}_{\mathrm{pl}}{ }^{0.7} \mathrm{~g}^{0.2}}{\rho_{\mathrm{v}}^{0.25} \mathrm{~h}_{\mathrm{fg}}{ }^{0.4} \mu_{\mathrm{l}}^{0.1}}\right)\left(\frac{\mathrm{P}_{\mathrm{v}}}{\mathrm{P}_{\mathrm{atm}}}\right)^{0.3} \mathrm{q}^{0.4} \\
\mathrm{~h}_{\mathrm{co}}=0.707\left(\frac{\rho_{\mathrm{l}}\left(\rho_{\mathrm{l}}-\rho_{\mathrm{v}}\right) \mathrm{g} \mathrm{k}_{\mathrm{l}}{ }^{3} \mathrm{~h}_{\mathrm{fg}}}{\mu_{\mathrm{l}}\left(\mathrm{T}_{\mathrm{sat}}-\mathrm{T}_{\mathrm{w}}\right) \mathrm{l}_{\mathrm{c}}}\right)^{\frac{1}{4}}
\end{gathered}
$$

Subsequently, the predicted overall thermal resistance can be calculated such that:

$$
\mathrm{R}_{\mathrm{th}, \mathrm{pre}}=\frac{1}{\mathrm{~h}_{\mathrm{e}} \mathrm{A}_{\mathrm{e}}}+\frac{1}{\mathrm{~h}_{\mathrm{c}} \mathrm{A}_{\mathrm{c}}}
$$

The results of the predicted overall thermal resistance are shown in Figure 9. It is obvious that predicted values of thermal resistance are in line with the experimental data, especially at high filling ratios. This is because the thermal resistance can be well described by the boiling heat transfer correlation since the evaporator is fully flooded. Yet the influence of the ambient temperature on the overall thermal resistance is rather small as explained earlier. Note that a higher ambient temperature into the data rack leads to a higher heating load of the thermosiphon, and a lower thermal resistance accordingly. Analogous results were obtained by Fadhl et al. [23] who also concluded that the thermal resistance of the thermosiphon tends to increase at low heating input, while it was appreciably decreased at high heating inputs. Their results showed that thermal resistance becomes relatively stable at a specific high heating input. However, as shown in Figure 9, the measured overall thermal resistance of the thermosiphon at lower filling ratios (e.g., 10 30\%) are detectably higher than those of calculations. The departure amid the predictions and the experimental measurements is because of the starvation of evaporator at such low filling ratios where the heat transfer process in the evaporator is appreciably offset by the upper part of the evaporator where only single-phase heat transfer for vapor prevails. To sum up, thermal performance of the thermosiphon tends to get improved by raising the filling ratios. However, the performance may reach a plateau when the evaporator is fully flooded, and a further overfilling may impair the overall performance.

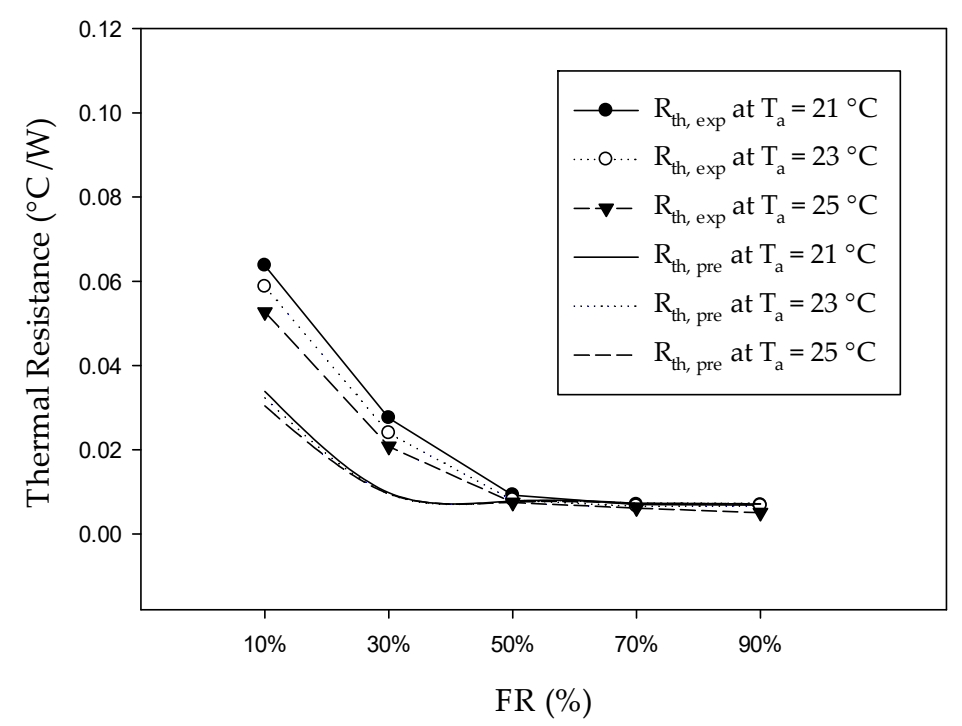

Figure 9. Experimental and predicted thermal resistance of the STPTL for different filling ratios, $\left(\mathrm{T}_{\mathrm{c}, \mathrm{i}}=15^{\circ} \mathrm{C}\right)$. 


\section{Conclusions}

This experimental study aims to investigate the energy saving potential by using a separated two-phase thermosiphon loop (STPTL) as a free cooling technique in datacenter. The thermosiphon heat exchanger takes the form as fin-and-tube configuration and is installed at the exit of a data rack. $\mathrm{R}-134 \mathrm{a}$ is used as the working fluid, and a water-cooled shell and tube heat exchanger is used as the condenser. The connected adiabatic piping, i.e., riser and downcomer, are made via PFA for easier installation and mobility consideration. The fin-and-tube thermosiphon heat exchanger is made of copper pipes and aluminum fins. The surface area of the thermosiphon is $1.11 \times 0.69 \mathrm{~m}^{2}$ including collector and header, and it consists of 48 vertical copper tubes with $9.52 \mathrm{~mm}$ nominal diameter (10.3 mm collar diameter after expansion). Tests are conducted with filling ratio ranging from 0 to $90 \%$ and the ambient temperatures varies from $21^{\circ} \mathrm{C}$ to $25^{\circ} \mathrm{C}$. Based on the foregoing discussions, the following conclusions can be derived:

1. The experimental results indicate that the energy saving increases with the rise of filling ratio. However, the optimum energy savings can be achieved at a filling ratio of $70 \%$, a further increase of filling ratio leads to a reduction in energy saving. A substantial energy savings of $38.7 \%$ can be achieved at the filling ratio of $70 \%$.

2. At a low filling ratio like $10 \%$, the evaporator starves for refrigerant and a very uneven air temperature distribution occurring at the exit of data rack. The uneven temperature distribution is relieved considerably when the evaporator is fully flooded.

3. It is also found that the energy saving is in line with the rise of system pressure. Overfilling of the evaporator may lead to a decline of system pressure. This is because the evaporator is fully flooded and only nucleate boiling prevails.

4. A lower overall thermal resistance occurs at high filling ratios and a higher ambient temperature. However, the effect of ambient temperature on the overall thermal resistance is negligible at high filling ratios. Yet appreciable increase in overall thermal resistance is encountered at low filling ratios due to the starvation of working fluid.

5. It is found that the overall thermal resistance is in line with the predictions especially at the high filling ratios.

Author Contributions: All the authors have contributed their efforts to complete the paper. H.M.D. conducted the experiments and wrote the first draft, M.W.S. provided technical assistance, K.-S.Y. supervised the experiment, and C.-C.W. supervised the work and review and editing the manuscript.

Funding: The authors are indebted to the financial support from the Ministry of Economics Affairs (Department of Industrial Technology), Taiwan, under grant number H301AR6100 and Ministry of Science and Technology, Taiwan under contracts 107-2622-E-009-002-CC2 and 107-2221-E-009-142.

Conflicts of Interest: The authors declare no conflict of interest.

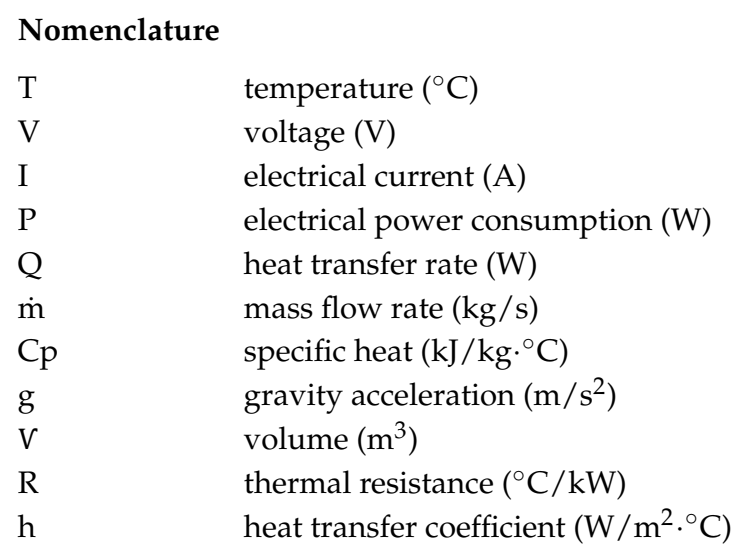




$\begin{array}{ll}\mathrm{A} & \text { area }\left(\mathrm{m}^{2}\right) \\ \mathrm{P} & \text { pressure }(\mathrm{kPa}) \\ \mathrm{q} & \text { heat flux }\left(\mathrm{W} / \mathrm{m}^{2}\right) \\ \mathrm{h}_{\mathrm{fg}} & \text { latent heat }(\mathrm{kJ} / \mathrm{kg}) \\ l & \text { length }(\mathrm{m})\end{array}$

\section{Greek symbols}

$\rho$

$k$

$\mu$

\section{Subscripts}

a

c

i

o

e

avg

ai

ao

1

ac

f

tr

$\mathrm{t}$

ch

wa

$\mathrm{p}$

w

sat

$\mathrm{h}$

$\mathrm{H}$

th

b

co

$v$

atm

$\exp$

pre

density $\left(\mathrm{kg} / \mathrm{m}^{3}\right)$

thermal conductivity $\left(\mathrm{W} / \mathrm{m} \cdot{ }^{\circ} \mathrm{C}\right)$

Dynamic viscosity (Pa.s)

ambient
condenser
inlet
outlet
evaporator
average
air inlet
air outlet
liquid
air conditioner
fans
traditional
total
chiller
water
pump
wall
saturation
hot air
heater
thermal
pool boiling
film condensation
vapor
atmospheric
experimental
predicted

Abbreviations

STPTL separated two-phase thermosiphon loop

CRAC computer room air-conditioning

ISMT integrated system of mechanical refrigeration and thermosiphon

PFA perfluoroalkoxy

T.S thermosiphon

AC air conditioner

T.C thermocouple

PWM pulse-width modulation

RTD resistance temperature detector

FR filling ratio

COP coefficient of performance

P.C power consumption

E.S energy savings

SD standard deviation 


\section{References}

1. Zhang, H.; Shao, S.; Jin, T.; Tian, C. Numerical investigation of a $\mathrm{CO}_{2}$ loop thermosyphon in an integrated air conditioning system for free cooling of data centers. Appl. Therm. Eng. 2017, 126, 1134-1140. [CrossRef]

2. Daraghmeh, H.M.; Wang, C.-C. A review of current status of free cooling in datacenters. Appl. Therm. Eng. 2017, 114, 1224-1239. [CrossRef]

3. Han, L.; Shi, W.; Wang, B.; Zhang, P.; Li, X. Development of an integrated air conditioner with thermosyphon and the application in mobile phone base station. Int. J. Refrig. 2013, 36, 58-69. [CrossRef]

4. Zhang, H.; Shao, S.; Xu, H.; Zou, H.; Tian, C. Integrated system of mechanical refrigeration and thermosyphon for free cooling of data centers. Appl. Therm. Eng. 2015, 75, 185-192. [CrossRef]

5. Zhang, H.; Shao, S.; Tian, C. Simulation of the Thermosyphon Free Cooling Mode in an Integrated System of Mechanical Refrigeration and Thermosyphon for Data Centers. Energy Procedia 2015, 75, 1458-1463. [CrossRef]

6. Ding, T.; Cao, H.W.; He, Z.G.; Li, Z. Experiment research on influence factors of the separated heat pipe system, especially the filling ratio and Freon types. Appl. Therm. Eng. 2017, 118, 357-364. [CrossRef]

7. Zhou, F.; Tian, X.; Ma, G. Investigation into the energy consumption of a data center with a thermosyphon heat exchanger. Chin. Sci. Bull. 2011, 56, 2185-2190. [CrossRef]

8. Zheng, Y.; Li, Z.; Liu, X.; Tong, Z.; Tu, R. Retrofit of air-conditioning system in data center using separate heat pipe system. In Proceedings of the 8th International Symposium on Heating, Ventilation and Air Conditioning; Springer: Berlin/Heidelberg, Germany, 2013; pp. 685-694.

9. Chehade, A.; Louahlia-Gualous, H.; Le Masson, S.; Lépinasse, E. Experimental investigations and modeling of a loop thermosyphon for cooling with zero electrical consumption. Appl. Therm. Eng. 2015, 87, 559-573. [CrossRef]

10. Tong, Z.; Ding, T.; Li, Z.; Liu, X.-H. An experimental investigation of an R744 two-phase thermosyphon loop used to cool a data center. Appl. Therm. Eng. 2015, 90, 362-365. [CrossRef]

11. Tong, Z.; Liu, X.-H.; Li, Z.; Jiang, Y. Experimental study on the effect of fill ratio on an R744 two-phase thermosyphon loop. Appl. Therm. Eng. 2016, 99, 302-312. [CrossRef]

12. Ong, K.S.; Haider-E-Alahi, M. Performance of a R-134a-filled thermosyphon. Appl. Therm. Eng. 2003, 23, 2373-2381. [CrossRef]

13. Zhang, H.; Shao, S.; Xu, H.; Zou, H.; Tang, M.; Tian, C. Simulation on the performance and free cooling potential of the thermosyphon mode in an integrated system of mechanical refrigeration and thermosyphon. Appl. Energy 2017, 185, 1604-1612. [CrossRef]

14. Zhang, H.; Shao, S.; Xu, H.; Zou, H.; Tang, M.; Tian, C. Numerical investigation on integrated system of mechanical refrigeration and thermosyphon for free cooling of data centers. Int. J. Refrig. 2015, 60, 9-18. [CrossRef]

15. Zhang, P.; Wang, B.; Wu, W.; Shi, W.; Li, X. Heat recovery from Internet data centers for space heating based on an integrated air conditioner with thermosyphon. Renew. Energy 2015, 80, 396-406. [CrossRef]

16. Ling, L.; Zhang, Q.; Yu, Y.; Liao, S.; Sha, Z. Experimental study on the thermal characteristics of micro channel separate heat pipe respect to different filling ratio. Appl. Therm. Eng. 2016, 102, 375-382. [CrossRef]

17. Zhang, H.; Shi, Z.; Liu, K.; Shao, S.; Jin, T.; Tian, C. Experimental and numerical investigation on a $\mathrm{CO}_{2}$ loop thermosyphon for free cooling of data centers. Appl. Therm. Eng. 2017, 111, 1083-1090. [CrossRef]

18. Lin, T.F.; Lin, W.T.; Tsay, Y.L.; Wu, J.C.; Shyu, R.J. Experimental investigation of geyser boiling in an annular two-phase closed thermosyphon. Int. J. Heat Mass Transf. 1995, 38, 295-307. [CrossRef]

19. Khazaee, I.; Hosseini, R.; Noie, S.H. Experimental investigation of effective parameters and correlation of geyser boiling in a two-phase closed thermosyphon. Appl. Therm. Eng. 2010, 30, 406-412. [CrossRef]

20. Jouhara, H.; Fadhl, B.; Wrobel, L.C. Three-dimensional CFD simulation of geyser boiling in a two-phase closed thermosyphon. Int. J. Hydrogen Energy 2016, 41, 16463-16476. [CrossRef]

21. Imura, H.; Kusuda, H.; Ogata, J.-I.; Miyazaki, T. Sakamoto, Heat transfer in two-phase closed-type thermosyphons. Nasa ADS 1979, 45, 712-722. 
22. Jouhara, H.; Robinson, A.J. Experimental investigation of small diameter two-phase closed thermosyphons charged with water, FC-84, FC-77 and FC-3283. Appl. Therm. Eng. 2010, 30, 201-211. [CrossRef]

23. Fadhl, B.; Wrobel, L.C.; Jouhara, H. Numerical modelling of the temperature distribution in a two-phase closed thermosyphon. Appl. Therm. Eng. 2013, 60, 122-131. [CrossRef] 